\title{
MODIFICATION EFFECTS OF MICROSECOND HIGH CURRENT ELECTRON BEAM EXPOSURE ON TITANIUM VT22 ALLOY
}

\author{
S. Ye. Donets ${ }^{I}$, V.F. Klepikov ${ }^{1}$, V.V. Lytvynenko ${ }^{1}$, E.M. Prokhorenko ${ }^{1}$, O.A. Startsev ${ }^{1}$, \\ Yu.F. Lonin", A.G. Ponomarev', V.T. Uvarov ${ }^{2}$, R.I. Starovoytov ${ }^{3}$ \\ ${ }^{1}$ Institute of Electrophysics and Radiation Technologies, Kharkiv, Ukraine; \\ ${ }^{2}$ National Science Center “Kharkov Institute of Physics and Technology”, Kharkiv, Ukraine; \\ ${ }^{3}$ V.N. Karazin Kharkiv National University, Kharkiv, Ukraine \\ E-mail:vvlytvynenko@ukr.net
}

Titanium VT22 alloy was irradiated in the TEMP-A accelerator with the high current electron beam with the energy of $350 \mathrm{keV}$, beam current of $2 \mathrm{kA}$, pulse length around $5 \mu \mathrm{s}$, and beam diameter of $45 \mathrm{~mm}$. The irradiation was performed for three samples with 1 to 3 pulses separately. Numeric simulations of the temperature distributions in the targets were conducted using the thermoelastic ablation model. The microstructural and mechanical properties of the irradiated alloy were studied using microhardness testing, metallography and fractography analysis.

PACS: 07.05.Tp, 44.90.+c, 61.80.Fe, 81.40.Wx

\section{INTRODUCTION}

One of the unique techniques for modification and testing of the thermo-mechanical properties of materials is the high-current electron beam irradiation (HCEB) [1]. Surface treatment of targets is performed by HCEB in a pulse mode with a duration of $10^{-8} \ldots 10^{-5} \mathrm{~s}$. The energy of HCEB beams is defined mostly in a range from tens of kiloelectronvolt to few megaelectronvolt, and a current density is up to $10^{4} \mathrm{~A} / \mathrm{cm}^{2}$. Such treatment is the advanced technique for surface modification which complements other techniques such as laser texturing [2].

HCEB irradiation of a metallic target leads to fast heating, development of the plasma/melt cloud of ablated material, generation of structural defects, etc. [3 -5]. While the absorbed dose distribution on the solids are not homogeneous, the modified target volume contains the following distinct zones: a quenched zone (QZ) which lays on a surface of a sample, a heat affected and melted zone (HAZ) in a subsurface volume below QZ, and a zone influenced by high dynamic stresses which further fades into a non-irradiated material. The formation of the first two zones are caused predominantly by the temperature and deformation fields and cooling rates. The material in the last zone becomes modified due to generation of structural defects caused by propagation of shock waves, and this zone is called the shockwave affected zone (SWZ). In the case of relativistic HCEBs, the contribution of shock waves becomes important primary due to a high volume of materials ablated from the surface, leading to development of the plasma/gas/melt cloud ejected from the target during evaporation. Defect formation in SWZ is also a result of stress induced by the differences in thermal expansion between the irradiated surface layer and the initial material. This phenomenon always occurs in the irradiated target disrespectfully to the energy and fluence of HCEB. If the thickness of a target few times exceeds the depth of HAZ, then this zone may form and later studied. If the thickness of a target is roughly less than 3 penetration depth of the beam, then a target may fracture. The detailed studies of the ablation processes under influence of HCEB can be found in [3 - 5].

The aim of this research is to study the modification effects in the titanium VT22 alloy after the intense elec- tron beam exposure of microsecond duration. The VT22 alloy is the near- $\beta$ titanium alloy, which chemical composition is: $79.4 \ldots 86.3 \mathrm{Ti}, 4.4 \ldots 5.7 \mathrm{Al}, 4 \ldots 5.5 \mathrm{Mo}$, 4...5.5 V, $0.5 \ldots 1.5 \mathrm{Cr}, 0.5 \ldots 1.5 \mathrm{Fe},<0.3 \mathrm{Zr},<0.15 \mathrm{Si}$, $<0.1 \mathrm{C}$, in wt.\%. This article focuses on the highstrength titanium VT22 alloy because this alloy has a wide industrial application. It is a well-studied material and this facilitates the investigation of the modification effects. The maximum applied exposure is limited to 3 consequent pulses of HCEB. Multiple pulse exposure intends to reveal the specific mass loss due to the ablation processes. This paper presents the results of the numeric simulation of the corresponding HCEB-target interaction which enables better understanding of the effects observed experimentally. Worth noting, the presented results are preliminary because the experimental investigations of all irradiated samples are ongoing.

\section{MATERIALS AND METHODS}

Three titanium plates were cut from a large plate, and their thickness was $3 \mathrm{~mm}$ (Table). All surfaces before irradiation were mechanically polished with $12 \mu \mathrm{m}$ polish paper. In the case of consecutive irradiations, only one side was irradiated.

The specimens were irradiated at the TEMP-A pulsed e-beam accelerator in the NSC Kharkiv Institute of Physics and Technology. The parameters of the beam were the following: the current of $2 \mathrm{kA}$, electron energy $\sim 350 \mathrm{keV}$, impulse duration $\tau_{p} \sim 4 \mu \mathrm{s}$. The duration of an impulse was measured from the oscilloscope graph (Fig. 1). The voltage was defined from the $\mathrm{CH} 1$ channel using a non-inductive voltage divider. The beam current was measured using a Rogowksi coil fixed around a sample holder rod. All irradiations were performed with a beam of a solid shape of cross-section, which had a diameter around $45 \mathrm{~mm}$. The intensity distribution in the cross-section was Gaussian. The peak fluence was taken to be around $250 \mathrm{~J} / \mathrm{cm}^{2}$. Irradiation was conducted under the pressure of about $10^{-5}$ Torr. In the case of multiple impulses, a pause between impulses was around $15 \mathrm{~min}$, which was enough to cool down the samples and to measure the difference in the mass due after ablation. For this reason, the samples were taken out into normal atmosphere, and then put back to the vacuum chamber. 


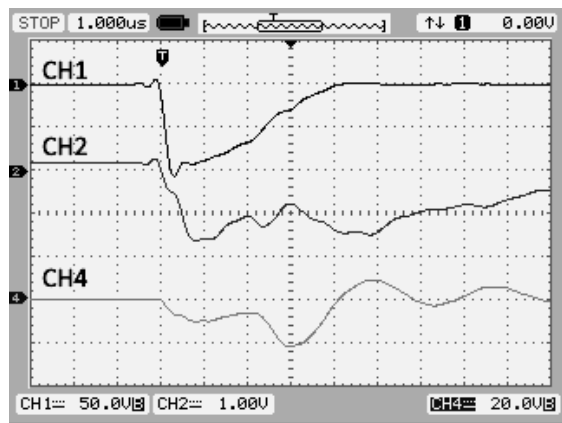

Fig. 1. Oscilloscope graph of the HCEB impulse generated at the TEMP-A accelerator facility, where 1 grid on the horizontal scale equals $1 \mu$ s. Chanel CHI defines the potential on a diode of the accelerator (1 grid equals $250 \mathrm{~V}$, and a scaling factor $=4000$ ), $\mathrm{CH} 2$ is a beam current (1 grid $=5 \mathrm{~V}$, and a scaling factor $=320$ ), and CH4 is a total diode current

Preliminarily centered according to the beam axis, the targets were irradiated perpendicularly to their surfaces. The specimens for metallography, fractography and hardness measurements were taken in the epicenter zone of the e-beam impact in the sample irradiated 3 times. The samples irradiated with 1 and 2 impulses were not studied yet using these techniques.

For fractography analyzes, the fractionation of the sample cooled with LN2 was performed manually by bending rupture. The fractography analyzes of the crossfracture were conducted using the scanning electron microscope JEOL JSM-840.

Having performed the fractography analyzes, the cross-sections were prepared for metallographic and hardness analyzes. The specimens were polished using a micron diamond powder W0-1. The water solution of $2 \mathrm{vol} \% \mathrm{HF}$ and $5 \mathrm{vol} \% \mathrm{HNO}_{3}$ and a hold time of $4 \ldots 6 \mathrm{~s}$ was used to etch the specimens to reveal the peculiarities of the microstructure.

The hardness $\mathrm{H}_{200}$ properties of the VT22 alloy after modification were analyzed using the PMT-3 microhardness testing machine equipped with a Vickers indenter. All measurements were done with a load of $200 \mathrm{kgf}$, the step between indents was around $100 \mu \mathrm{m}$. The methodology of the analyses and data treatment are described elsewhere [6]. The indentation was conducted only for the sample irradiated with 3 impulses. The cross-section was taken at the epicenter of the crater.

Prior to the experiments, the numerical simulations of the HCEB exposures were performed using the finite element and finite difference approaches. The applied model in this research is the 2D thermoelastic ablation model previously developed in $[7,8]$. The modelling was conducted in the free-source software FreeFem++3.61v. The corresponding physical and mechanical parameters of the VT22 alloy were taken for simulations from the literature data provided in [9]. As an outcome, there were calculated the temperature field evolution in the specimens, which were used for the explanation of experimental results. The data post-treatment was done in a trial version of Wolfram Mathematica.

\section{RESULTS AND DISCUSSION}

The numerical simulation of the HCEB irradiation were performed only for the impact of one impulse. The samples after each irradiation cooled down to a room temperature in order to weight them.

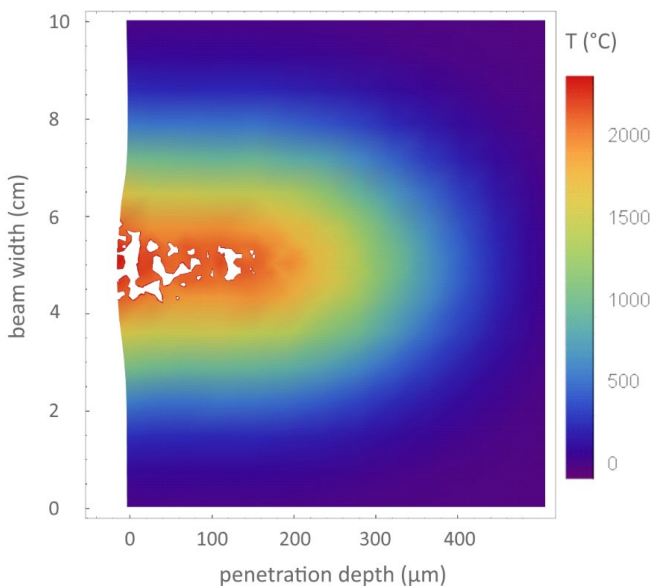

Fig. 2. 2D temperature field distribution in a target of the VT22 alloy after a single impulse of HCEB

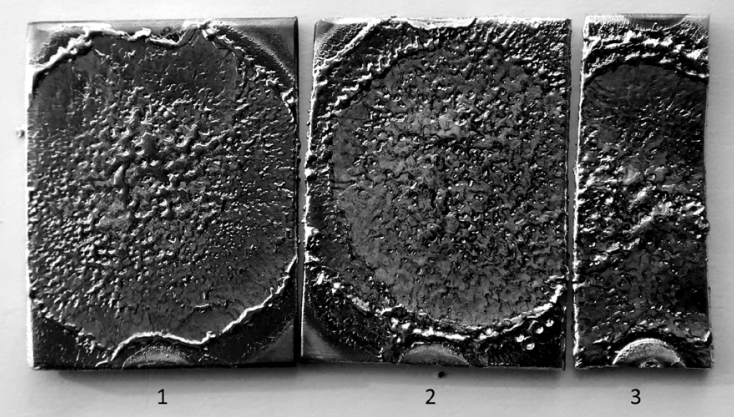

Fig. 3. The samples of VT22 alloy after irradiations with HCEB. The numbers represent the number of applied impulses after completion of the experiments

To simplify the modelling, the effect of the previous irradiation on the next impact was neglected. The only valuable effect is assumed to be deepening of a crater of the sample, but it precise quantification is beyond the scope of the present research. The value, which is in scope is a mass loss of the target. The mass loss was calculated by integrating the ejected melt, which was not back condensed to the target. Fig. 2 shows a temperature distribution in the sample of the VT22 alloy after 1 impulse of $\mathrm{HCEB}$, at $4 \mu \mathrm{s}$. The presented figure includes only the early development of the crater and the complete propagation dynamics of the melt cloud into the vacuum chamber was intentionally cut off. The white space in the crater denotes the voids in the $2 \mathrm{D}$ projection where the medium already ejected outside the system prior to the end of irradiation. The dynamics of the melt/gas/plasma cloud will be discussed in further articles.

In simulations, there was a necessity to utilize an additional coefficient, namely the empiric ratio of transmitted energy to a target. It is denoted as a fraction $\mathrm{J} / \mathrm{J}_{\mathrm{t}}$, where $\mathrm{J}$ is an energy theoretically provided to a target, and $\mathrm{J}_{\mathrm{t}}$ is a total energy of the beam $(2.8 \mathrm{~kJ})$. $\mathrm{J}$ was calculated for each sample, regarding its dimensions and the trace of the beam left on the surface after irradiation.

Fig. 3 shows the samples after irradiations. From the traces of the irradiations, it was observed, that the beam did not completely covered the surface of each target. and, the transmitted energies to the targets were estimated (Table). 
The parameters of the samples irradiated in the study. The parameters highlighted in italics denote the empiric/calculated values taken for/from simulation

\begin{tabular}{|c|c|c|c|c|c|c|}
\hline $\left.\begin{array}{c}\text { Linear dimen- } \\
\text { sions } \\
(w \times \\
\mathrm{x} t\end{array}\right), \mathrm{mm}$ & $\begin{array}{c}\mathrm{Nb} \\
\text { of impuls- } \\
\text { es }\end{array}$ & $\begin{array}{c}\text { Empiric ratio } \\
\text { of transmitted } \\
\text { energy }\end{array}$ & $\begin{array}{c}\text { Simulated } \\
\text { ablated } \\
\text { mass, } \mathrm{g}\end{array}$ & $\begin{array}{c}\text { Mass before } \\
\text { irradiation, } \mathrm{g}\end{array}$ & $\begin{array}{c}\text { Total } \\
\text { change } \\
\text { in mass, }\end{array}$ & $\begin{array}{c}\text { Specific change } \\
\text { in mass with } \\
\text { impulses, } \mathrm{g}\end{array}$ \\
\hline $46 \times 36 \times 3$ & 1 & 0.8 & 0.11 & $18.85 \pm 0.05$ & $0.13 \pm 0.01$ & - \\
\hline $46 \times 36 \times 3$ & 2 & 0.8 & 0.18 & $18.22 \pm 0.05$ & $0.20 \pm 0.01$ & $\begin{array}{c}0.07 \pm 0.01 \\
(1 \rightarrow 2)\end{array}$ \\
\hline $46 \times 17 \times 3$ & 3 & 0.38 & 0.19 & $8.52 \pm 0.05$ & $0.34 \pm 0.01$ & $\begin{array}{c}0.14 \pm 0.01 \\
(2 \rightarrow 3)\end{array}$ \\
\hline
\end{tabular}

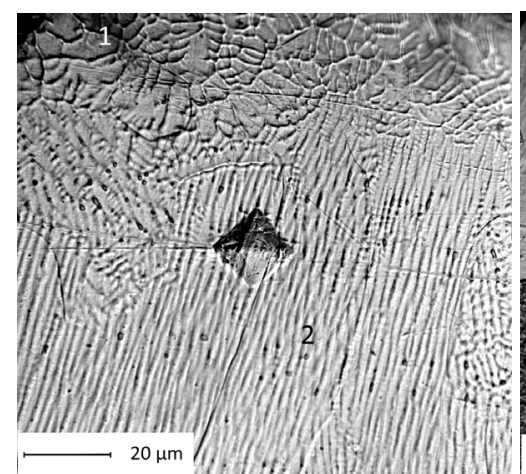

$a$

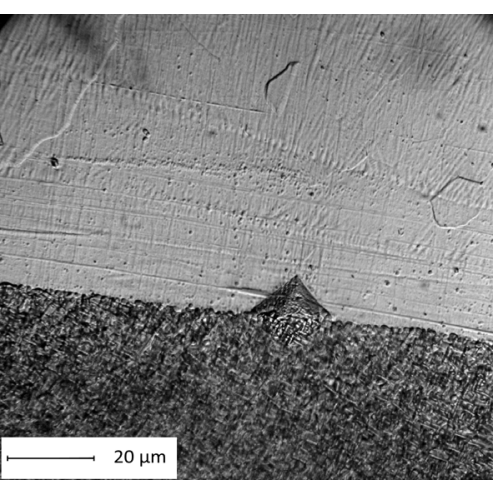

$b$

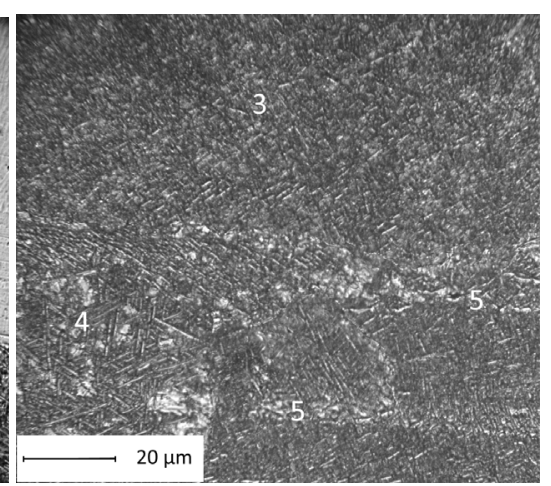

$c$

Fig. 4. Optical micrographs of the VT22 alloy after the HCEB irradiation: (a) QZ (1) at the top and HAZ (2) at the bottom, (b) HAZ at the top and the boundary of the melted region, in the middle, (c) the non-irradiated initial region at the bottom. Features of microstructure are numbered and explained in the text here below

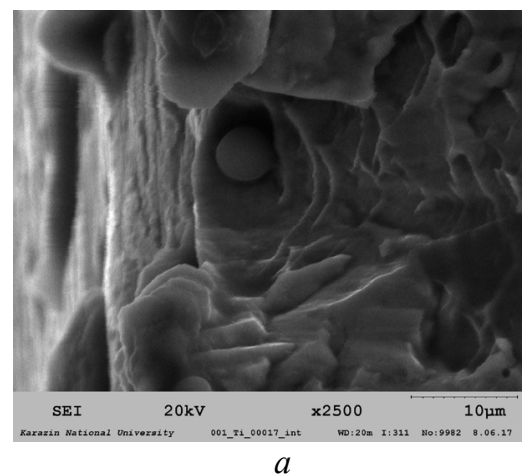

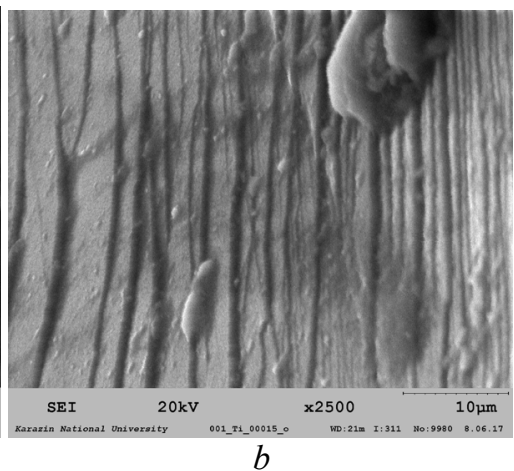

$b$

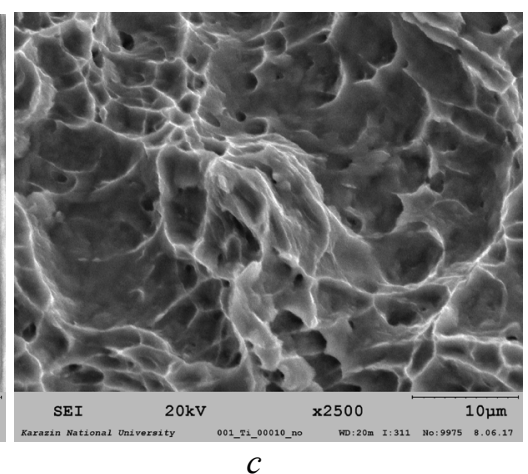

c

Fig. 5. Fractography images of the VT22 alloy sample: (a) QZ and (b) HAZ zones after HCEB irradiation;

(c) non-irradiated material

The changes in mass after irradiation were calculated from the numeric simulations. They underestimate the mass losses measured experimentally. This is considered to be induced by the deviations in the irradiation parameters (beam alignment and empiric ration of transmitted energy), and by the influence of the curvature of the surface under irradiation and corresponding melt dynamics/back condensation. These questions are currently under investigation, and they have to be addressed in future. From experiments, it appeared, that the relative the mass loss per impulse is nearly around of $\sim 0.1 \mathrm{~g} /$ impulse for the targets irradiated with 1 and 2 pulses. However, the great difference was detected for the smaller sample after 3 impulses, when the mass loss is about $\sim 0.11 \mathrm{~g} / \mathrm{impulse}$. If we take into account the correlation to the size of a sample, the corresponding mass loss is $\sim 0.29 \mathrm{~g} / \mathrm{impulse}$ as for the plates with a size of $46 \times 36 \times 3 \mathrm{~mm}$. Such $3 \times$ increase in the mass loss is linked only with the back condensation of the melt. The similar underestimation was made for the numeri- cally calculated mass loss. The mathematical model has to be upgraded to a more comprehensive description of the melt dynamics and back condensation. The crater effect also does not make the mass loss to be an invariant value for the multiple-pulse irradiations. The sample 1 and 2 (impulses $=$ notation) after application of the $1^{\text {st }}$ impulse had $0.13 \mathrm{~g} / \mathrm{impulse}$. But having been irradiated for the second time, the sample 2 lost $0.07 \mathrm{~g}$ (see Table). The large decrease is attributed to the walls of the crater with impedes the tangent movement of the melt. The melt from the bulk of the crater is removed by the normal component of the ablation ejection. In contrary, the smaller sample after 3 impulses had a greater degree of freedom for the ejection of the melt due to the smaller crater effect.

Thus, it is reasonable to conduct more experiments on the samples with different geometric shape to estimate the normal and tangent component of the melt movement, or roughly, of the mass loss due to transfer. The samples with a cross-section smaller $1 \mathrm{~cm}^{2}$ are eli- 
gible to eliminate the crater effect, and the needle-like samples will minimize the normal component, while the samples large enough to capture the full trace of the beam will have a smaller tangent component. This data is also vital for development of new technologies of electro-erosion coating [10].

Metallographic analyzes of the sample irradiated with 3 impulses revealed the specifics of the modified microstructure. The microstructure is heterogeneous, and there were observed QZ, HAZ zones. The presence of the SWZ was not confirmed using the available analysis techniques. The microstructure in QZ (see Fig. 4, mark 1) zone consists of the equaixed dendrites, with heterogeneously distributed grains due to absence of preferred orientation during solidification. The thickness of QZ layer is in the range $30 \ldots 50 \mu \mathrm{m}$. The average grain sizes were measured by the chord intercept method, and it was around 5...9 $\mu \mathrm{m}$. QZ with depth transforms in HAZ (see Fig. 4,a, mark 2). HAZ has the lamellar dendritic microstructure, but its grains are aligned along the direction of the thermal flow (i.e. normally to the surface). The dendrites were formed as elongated crystallites of primary crystallization during solidification from the liquid phase. Appearance of this microstructure was driven by the thermal flow into the bulk and by the small tangent component of the mass transfer. Such dendritic structure preserves until the boundary with the non-melted material. The smaller grain axis size was around $2 \ldots .5 \mu \mathrm{m}$. The large axis reaches up to $100 \mu \mathrm{m}$ in length.

The non-melted near-boundary material is also modified after experiencing the elevated temperatures conducted from the melt resulting in formation of coarser martensite $a+\beta$ structure. In this non-melted region, $\beta$ recrystallization and $\alpha$ precipitation are possible, as the temperatures reach higher than $700 \ldots 750^{\circ} \mathrm{C}$. At this temperature, first recrystallization was observed by Gao et al. in [11]. Finally, at the depth around $0.6 \mathrm{~mm}$ from the surface, the initial non-modified microstructure was observed. It consists of the mixed tempered structure of the very fine acicular martensite $\alpha$ (see Fig. 4, mark 3), and the fine acicular martensite $a+\beta$ (see Fig. 4, mark 4 ). The corresponding grain sizes were not estimated due to the limits of optical resolution. In the $a+\beta$ areas, the prior- $\beta$ grain boundaries were also observed (see Fig. 3,c, mark 5).

The morphology of the fractures in the irradiated area and the non-irradiated area of the sample were investigated (see Fig. 5). In QZ, we observed a quasi-ductile character of fracture with elements of a ductile dimples and inter crystallite cracks. Some spherical precipitates with a diameter up to $4 \mu \mathrm{m}$ were found to be stress concentrators. Their chemical nature was not studied yet, but it is speculated, that they represent grains of $\alpha$ phase as in [11]. HAZ had a quasi-brittle micro and macro mechanism of fracture. The 'brittle' cracks were distributed at the dendrite grain boundaries. However, some dimpled typology at a microscale was observed. Thus, HAZ carries the characteristics of both the ductile and brittle fracture modes. The non-irradiated initial material was characterized by a classic ductile fracture with fine dimples and facets. It can be stated, that the HCEB irradiation induces brittleness of the newly formed microstructures.

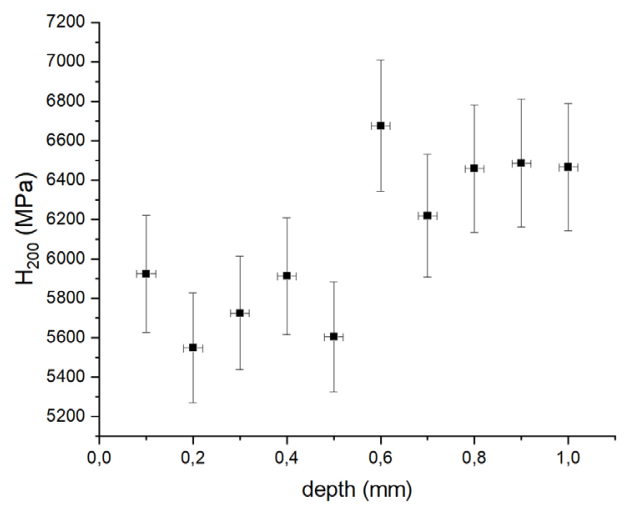

Fig. 6. Hardness indentation testing of the HCEB irradiated VT22 sample in the epicenter zone

The hardness $\mathrm{H}_{200}$ was tested for the sample irradiated 3 times. The corresponding hardness profile versus depth at the epicenter of exposure is represented on Fig. 6. The melted layer HAZ extends for about $600 \mu \mathrm{m}$, and it has microhardness $H_{200}{ }^{\circ} \sim(5.7 \pm 0.3) \mathrm{GPa}$. The reference non-irradiated metal has of the modified material $H_{200}{ }^{\circ} \sim(6.5 \pm 0.3) \mathrm{GPA}$. The decrease in hardness is explained by the formation of the relatively dendritic microstructure in the melted layer (see Fig. 4). The hardness testing of the thin QZ layer is planned to be conducted soon, and the expected results should be lower than for HAZ due to its heterogeneous equaixed nature. The equaixed dendrite microstructure (see Fig. 5,a,b) should attribute to the decrease in the hardness.

Regarding the modification effects and incompletion of the physical model to simulate the intense electronbeam exposure of the metallic targets, it is proposed to continue the current study [12 - 14]. Future in-depth investigations on the melt dynamics and the tangent/normal components of mass transfer of the melt in the crater and detailed study of the back condensation are of great importance for further progress in practical application of the HCEB irradiations.

\section{CONCLUSIONS}

HCEB irradiation of the technical titanium alloy VT22 was performed in this study. The samples were irradiated with 1 to 3 impulses, and the mass loss due to ablation was analyzed. It was observed, that the normal and tangent components of the mass transfer due to the effect of the crater wall are of great importance. With formation of the crater wall, the mass loss per impulse decreases. If the crater effect is minimized as for the small samples, the mass loss increases. The irradiation resulted in formation of a layer with a dendritic microstructure after solidification compared to the martensitic non-irradiated metal. The quenched zone of the melted layer has the quasi-ductile fracture character compared to the ductile character of the base metal. The heataffected zone shows a quasi-ductile fracture mechanism, it also has some elements of dimpled ductile fracture at microscale. The melted layer has a reduced microhardness compared to the non-irradiated metal caused by the dendritic microstructure. 


\section{ACKNOWLEDGMENT}

The research presented in this article was conducted by financial support of the state budget program "Support for the development the priority areas of scientific researches" (Budget Financial Code 6541230).

\section{REFERENCES}

1. Jr.S. Humphries. Principles of high current electron beam acceleration // Nuclear Instruments and Methods in Physics Research Section A: Accelerators, Spectrometers, Detectors and Associated Equipment. 1987, v. 258, iss. 3, p. 548-565.

2. B. Antoszewski and V. Tarelnyk. Laser Texturing of Sliding Surfaces of Bearings and Pump Seals // Applied Mechanics and Materials. 2014, v. 630, p. 301-307.

3. C. Dong et al. Surface treatment by high current pulsed electron beam // Surface and Coatings Technology. 2003, v. 163-164, p. 620-624.

4. V.F. Klepikov et al. Dynamics of the gas-plasma torch formed by the high-current electron beam action on solid targets // Problems of Atomic Science and Technology. Series "Plasma Physics". 2009, № 1, p. 119-121.

5. A.G. Kobets et al. Melting effects of high-current relativistic electron beam on aluminum alloy 1933 // Surface Engineering and Applied Electrochemistry. v. 51, № 5, p. 478-482.

6. ASMA. Manual of PMT-3 microhardness testing indenter. 2018, 17 p.

7. V.F. Klepikov, Yu.F. Lonin, A.G. Ponomarev, O.A. Startsev, V.T. Uvarov. Physical and mechanical properties of titanium alloy VT1-0 after high-current electron beam irradiation // Problems of Atomic Science and Technology. Series "Physics of Radiation Effect and Radiation Materials Science”. 2015, № 2, p. 39-42.
8. V.F. Klepikov et al. Fractality of fractures of aluminum and titanium alloys irradiated by intensive electron beam // Journal of Nano- and Electronic Physics. 2016, v. 8, № 3, p. 03009.

9. V.N. Moiseev. High strength titanium alloys in aircraft construction // Tech Light Alloys. 2002, № 4, p. 77-80.

10. V.B. Tarelnyk et al. Investigation of Regularities of the Processes of Formation of Surface Layers with Electroerosive Alloying. Part II // Metallofiz. Noveishie Tekhnol. 2017, 39, № 3, p. 363-385 (in Russian).

11. J. Gao et al. Segregation mediated heterogeneous structure in a metastable $\beta$ titanium alloy with a superior combination of strength and ductility // Scientific Reports. 2018, 8:7512.

12. V.T. Uvarov et al. Radiation acoustic control over the thermal parameter of construction materials irradiated by intense relativistic electron beam // Phys. of Part. and Nucl. Latter. 2014, v. 11, №. 3, p. 274-281.

13. A.B. Batracov et al. The particularities of the high current relativistic electron beams influence on construction materials targets // Problems of Atomic Science and Technology. Series "Nuclear Physics Investigations”. 2013, № 6, p. 225-229.

14. V.F. Klepikov et al. The formation of strengthening coats by microsecond duration high-current relativistic electron beam // Problems of Atomic Science and Technology. Series "Nuclear Physics Investigations”. 2008, № 5, p. 91-95.

Article received 17.05.2019

\section{МОДИФИЦИРУЮЩИЕ ЭФФЕКТЫ В СПЛАВЕ ТИТАНА ВТ22 ПОД ВОЗДЕЙСТВИЕМ МИКРОСЕКУНДНОГО СИЛЬНОТОЧНОГО ЭЛЕКТРОННОГО ПУЧКА \\ С.Е. Донец, В.Ф. Клепиков, В.В. Литвиненко, Е.М. Прохоренко, А.А. Старцев, Ю.Ф. Лонин, А.Г. Пономарёв, В.Т. Уваров, Р.И. Старовойтов}

Титановый сплав ВТ22 облучен в ускорителе ТЕМР-А сильноточным электронным пучком с энергией 350 кэВ, током пучка 2 кА, длиной импульса около 4 мкс и диаметром пучка 45 мм. Облучение проводили для трех образцов 1-3 импульсами. Численное моделирование распределения температуры в мишенях проводилось с использованием модели термоупругой абляции. Микроструктурные и механические свойства облученного сплава были изучены с использованием измерения микротвердости, металлографического и фрактографического анализов.

\section{ЕФЕКТИ МОДИФІКАЦЇ̈ В ТИТАНОВОМУ СПЛАВІ ВТ22 ПІД ДІЕЮ ОПРОМІНЕННЯ МІКРОСЕКУНДНИМ СИЛЬНОСТРУМОВИМ ЕЛЕКТРОННИМ ПУЧКОМ

\author{
С.С. Донець, В.Ф. Клепіков, В.В. Литвиненко, С.М. Прохоренко, О.А. Старцев, Ю.Ф. Лонін, \\ А.Г. Пономарьов, В.Т. Уваров, Р.І. Старовойтов
}

Сплав титану ВТ22 опромінювався в прискорювачі ТЕМР-А сильнострумовим електронним пучком 3 енергією 350 кеВ, струмом пучка 2 кА, довжиною імпульсу близько 4 мкс і діаметром пучка 45 мм. Опромінення проводили для трьох зразків 1-3 імпульсами. Чисельне моделювання розподілів температур у мішенях проводилося з використанням моделі термопружної абляції. Досліджено мікроструктурні та механічні властивості опроміненого сплаву з використанням вимірювання мікротвердості, металографічного та фрактографічного аналізів. 